\title{
The Use of Railways for Coast and Harbour Defence
}

\section{E. P. Girouard R.E.}

To cite this article: E. P. Girouard R.E. (1891) The Use of Railways for Coast and Harbour Defence, Royal United Services Institution. Journal, 35:160, 631-650, DOI: 10.1080/03071849109416569

To link to this article: http://dx.doi.org/10.1080/03071849109416569

\section{曲 Published online: 11 Sep 2009.}

Submit your article to this journal $\sqsubset x$

Џ Article views: 5 
Friday, April 24, 1891.

Major-Geseral R. N. DAWSON-SCOTT, Commandant, School of Military Engineering, Chatham, Member of Council, in the Chair.

\section{THE USE OF RAILWAYS FOR COAST AND HARBOUR DEFENCE.}

Bร 2nd Lient. E. P. Ginotard, R.E.

Ix approaching the study of the coast defence of Great Britain, one is at once confronted with the rexed question of what the nature of the defence should be.

Innumerable books and papers have been written upon tho sabject, and jet no clearly defined principles to act uponaro to be found. The gencral impression, however, after reading the moro modern views upon the sabject, is practically the same whether tho mind droll upon the infuence of the sporadic raider, which some contend to be our onls future foe, or upon the cscaped squadron and the invading foreigner. All degrees of opinion unito iu demanding some form of coast defence.

The opinions differ in the method of the defence only. None dispute the necessity of using guns and submarine mines or torpedoes for the local defence of our arsenals, docksards, and unprotected coast towns; though some differ as to the necessity of provision againgt in rasion.

All admit the wcakness, for a general local defence of the countrs, of our present system of cosst defence. It leares many of our commercial centres and const towns quite open to the insults of an eneny. Everywhere on sea and land our present defence is admitted to bo deficient in gan power. Eren if our Navs were in the strength we all hope to seo it, our coasts would, as defended at present, be in no condition of security from light attacks. What is argently needed is gun power; gun power to ward off the raider from our unprotected. towns and ports, if the. Navy is at its strongest; gun power to ward off any attack until the Nary reaches that point; and gun power to prevent landings upon our shorcs. Is this gun power to bo obtained by an extension of our morable const defence? Naral authorities themselves say no; all ships must for the present go towards strengthening our first. line of defence. Can this superiority of gun power be attained by an extension of fixed fortifications? Probably so at important points. But the extension of fixed fortifications of a modern type for the defenco of every. exposed point of our const is an 
utter impossibility. The cost of such an extension rould be enormous.

Gun porrer must be obtained, if possible. A moring coast defence on the present system cannot be provided for it, and the cost of a fixed coast defence is prohibitive.

There is, howerer, another system, which I beg to submit to the judgment of this andieuce : as .being one of some considerable promise.

In Grent Britain and Ireland wa hare systems of railwajs which are the admiration of the world.

Why not put this magnificent system to a practical usn for the defence of the country, mount guns upon trucks . which could travel on these lines and bo fired from them?

Of the existence of the network of railway lines which corer this country, creryone is doubtless aware. Probably but few, bowerer, have ever given a thonght to the fact that they suggest the truest and most cconomical basis for resistance to any aggression or insult on our shores. Their construction was of course due to commercial reasons only. 'But physical conditions havo determined for them in unany places a course close alongside the seaboard, aud thus they giro as all the necessary elements for a powerful line of defence along the exposed portions of our coast.

By their proper utilization the country conld be formed into one liuge fortress, and prompt communication ensured between the parts. Sach would be the elasticity of the system, that an encmy would have opposed to him at any.exposed point of tho const the armament of a first-class fortress.

Before proceeding to any details of a proposed system for coast defence based upon the use of our existing railways; I should like to invite attention more especially to one or two points, which the foregoing suggestions emplaasize.

Our esisting. system of coast defence 'by corst-defence ressels and fixed fortifications is an extremely partial one. It omits large portions of our coast line, whereas the system of defence here advocated is nniversally applicable to the whole coast line of Great Britain and Ireland. Morcover, it must be carefully borne in mind that ships and fortifications under modern conditions rapidly become obsolete, whereas our railwajs are alwajs bept in excellent working order by the companies concerned without any expense to the Gorerument, and are at the shortest notice ready to bring into action guns of the then latest and most improred pattern.

\section{Practical Examples of Firing Guns from Railuays.}

: Iefore proceedinz to the details of a proposed scheme one important point must be discussed and settled if possible.:

Can gans.be fired from an ordinary line of railway with any degrce of safety?

- If the gun is to be fired in the direction of the line or at a small 
angle to it, no difficulty.exists. . This method of fring guns is used in all arsenals for the proof of tho heaviest guns in existence.

But the fre will undoubtedly hare to be exercised orer a wide area, and in most cases at angles to the lines, if not actually at right angles to them. Can this be effected with safety? Theoretically I am able to say, yes. Using as a basis the results of actual experiments it will be found that the 6-inch B.L. gan of 5 tons may be theoretically fired at a right angle to the line.

Not feeling that.my authority for this statement would bear any weight, I asked Colonel Kensington, R.A., Professor of Artillery at the R.MI.A., if he would kindly assist me. He has been good enough to go into tho theory of the sabject; and has consented to say a few words on it at the conclusion of this paper.

$\Lambda$ series of rers raluable experiments was carried out at the Camp of Exerciso at Delhi in Jannary, 1886, to test the practicability of firing guns at right angles to an ordinary line of railway.

The gauge of the railway on which the experiments were carried out. (Rajputana Mralwa Line) was one of 1 metro or 3.37 feet.

The gan used was tho 40-pr. R.B.L. of $35 \mathrm{cwt}$. haring a mazzle velocity of 1,180 fect.per second.

The following trucks were requisitioned for the experiments :-

1. A 4.whecl ragon. Weight $2 \cdot 87$ tons. Iength 13 feet 5 inches. Width 6 feet $3 \frac{1}{2}$ inches.

2. An 8-wheel bogic track. Weight 5.36 tons. Floor dimensions $25 \times 7$ fect.

The conclusions of the members of the Experimental Committec were:-

MIr. Jones, Carriage Superintendent, Rajputana Mralna Railnay.' :

1. That 40-pr. guns can be fired with perfect safets broadside from citber-

(a.) Small empty wagons monnted on four whecls.

(b.) Small empty wagons weighted up to 4 tons.

(c.) Empty 8-wheel bogies.

2. That a bogice wagon weighted to $19 \cdot 4$ tons was perfectly stable when fired from broadside with a shotted 40-pr. gun. When so fired tho deflection of the wagon bearing springs was actually less than half an incl.

Najor Bissett, R.E., came to the same general conclusions as the above.

The sucecss of the aboro experimeats is rery remarkable if tho uatures of the carriages, and the fact that no attempt was made in any way to reduce the energy of recoil, be considered.

The difference rould, it is only just to assume, be cren more re-" markạble if-

lst. A lower and hearier carriage, specially designed for the purpose, wero nsed. : :

2 d. The recoil were taken up by the latest form of buffer.

3rd: The gun were fired from a 4 feet $8 \frac{1}{2}$ inch line, in lien of ouc of $3 \cdot 37$ feet. 
If it be recalled to mind that the 40-pr. R.B.L. gan has a mazzle re. locity of 1,180 feet per second, the following assumptions eren withont theoretical proof would not seem a lengthy flight of imagination. That presupposing the provision of a carriage specially adapted to the purpose, by the use of all modern improvenients, the firing of a 6-inch B.I. gun laving a muzzle velocity of 1,780 feet per second could be effected with safety from a standard gauge railway.

\section{- Proposed Organization for England.}

It was my intention, after pointing out the practical possibilities of fring gans from railways, to gire an outline of a proposed organi. zation for the defence of Great Britain by the use of our existing lines.

From want of time I hare been obliged to abandon my original idea, and limit this paper to England only.

The accompanyiner explanators map (No. 1) of the proposed schemo as applied to England has becn prepared on the basis of a range of 7,000 yards for gun fire and of 3,500 sards for machine-guns.

On this una the portions coloured red indicate water cosered up to 7,000 yards by the use of the railway lines. The green represents the zone of light Q.F. gun fire (3,500 yards). The black the areas which are inaccessiblo by reason of the presence of natural obstacles, fe. The chain dotted line indicates the position of the 5 -fathom line. The results obtained upon this map are of course purely of a theoretical character; undoubtedly cuttings and other obstractions in the feld of fire would, in the erent of a practical surres, be found to interfero in some places.

Starting from the Thames on this theoretical map it will be obserred that that estuary, and with it the Rirer Medway, are closed. Proceeding northwards, the first important point is the supposed favourable landing between the Rivers Crouch and Blackwater. To make grod a landing at this point, only forts-fire miles from London, an enemy must take adrantage of a pocket or channel north of the Ganflect Sand, called the Wallot.

Thence he could land between the Crouch and the Blackwater, and tako ap an excellent commanding position, facing London; or ho might land in a less favourable position between the Colne and the Stonr, on the beach of Clacton.

To reach the shore at the first-named place his boats would hase four miles to row at low tide, to resch the second abont three.

Within a range of 7,000 yards, as the map shows, the Wallet is to a great extent corered, and from an actual study of this particular piece of coast I am able to say that the practical limits of fire at this point would be identical with the theoretical results here shown. By a short extension of the railway from Claction towards the south, the whole of the Wallet might bo covered, and this dangerons point absolntely secured.

Leaving Clacton, the Stonr and the harbonr of Harwich are reached; these, being already defended, can be neglected. 


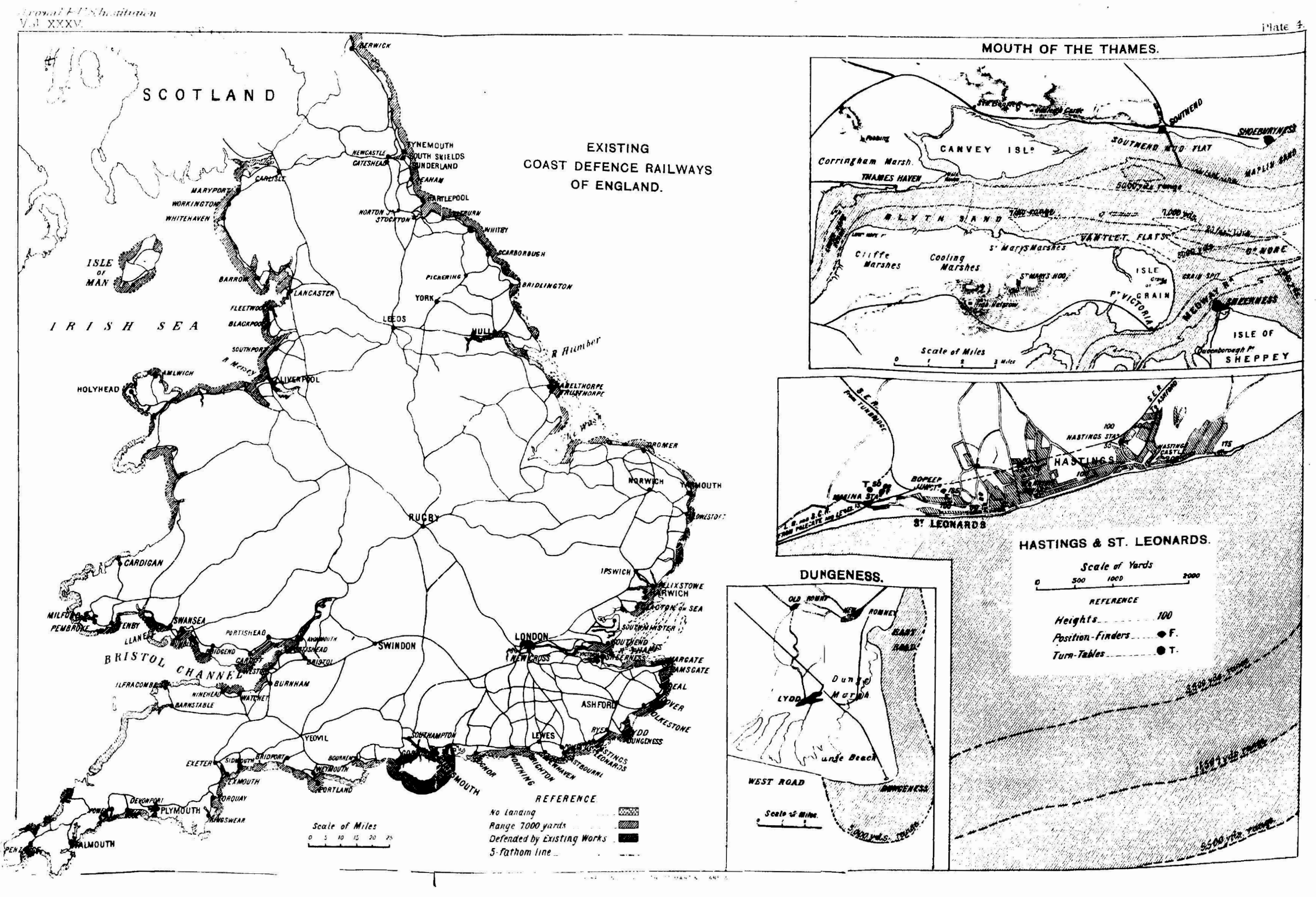


Then comes a short length of const which would be andefended except by a few ancient martellos. Following these are the intricate windings of the Ore, which make the corst practicall 5 inaccessible. Aldborough, Lowestoft, and Yarmouth are well defended. After them comes a length of 12 miles totally undefended, 120 miles from London, howerer; then Cromer and its ricinity, which are covered. And now the ragaries of the 5.fathom line, in the Wash, will permit us to leave it aside and cross to Theddlesthorpe, a possible landing, which can, however, be-secured. Again the 5-fathom line runs ont to sea, and the Humber is reached and closed. In the neighbourhood of Withernsea a possible landing exists, which is unsecured; this might, however, be remedied at small cost by a short extension of the line. From Bridlington north to the Border, 150 miles, the whole coast line is admirably defended on paper, and the towns of Bridling. ton, Scarborough, Whitby, Saltburn, Middlesborough, Seaham, Hartlepool, Sunderland, Shields, Tynemouth, and Berwick could bo protected.

A considerable portion of this coast is, however, inaccessible, and would in practice be neglected.

Crossing to the western coast, the accessible shores from the Solway to the Menai Strait are completely defended, including the ports of Barrow, Fleetwood, and Holyhead.

The western coast of Wales is not completely defended, but is in itself a sufficient obstacle.

In the Bristol Channel, Milford Haven, Llanelly, Swransea, Barry Docks, Cardiff, Aronmouth, and Bristol are covered.

The northern coast of Cornwall is in most places inaccessible; on its sonthern coast Penzance, Falmouth, and Fowey could be pro: tected. Plymouth and Portsmouth may be neglected; between the two, however, Kingswear, Torquay, Exmonth, and Sidmouth would be covered.

From Portsmouth to the Thames there is a coast line of 170 miles; and of this very important section 160 miles are defensible, and the unprotected towns of Worthing, Brighton, Eastbourne, Hastings, Folkestone, Margate, and Ramsgate, all at present quite open to insult, could probably defy an enemy.

Summarizing, the unsatisfactory portions of the coast railway. defence would be few and far between, and conld, if thought neces. sary, be remedied at a trifling cost.

In Table I the details of the coast line of the English counties aro given. In a total length of 1,900 miles of coast, 1,270 conld theoretically be defended from the railways; 425 are inaccessible, thus increasing the total defended to 1,695, or 89 per cent. of the whole.

Of the coast of the counties close to Irondon, and to the great manufacturing centres, namely; the counties of Lancashire, Cheshire, Norfolk, Suffolk, Essex, Sussex, Kent, and Dorset, 92 per cent. is defensible.

Every English coast town of the slightest importance is defended; every estuary and harbour the same.

(a.) The Subdivisicn of the Defence.-From the configuration of the 
const, the line to be taken in the subdivision of the defence is an obvious one.

1st. A South-eastern section.

2nd. A special defence for.the Thames.

3rd. The Hastern counties.

4th. The Lincolnshire coast.

5th. The cosst of Yorkshire.

(ith. The defences of the Middlesborough-Neweastlo district.

7th. A North-western section.

8th. A Bristol Channel section.

9tl. The Portsmouth and Southern district, the major part of which is already defeuded.

In addition, a few minor sections might have to be introduced. of-

Each of these sections would, as I propose, be organized into series

1st. Firing lines, consisting of guns stationed at rulnerable points along the coast, or concentrated at junctions from which they could readily move up to threatened points.

2nd. Supports placed at some central point of the sections, from which the firing lines wonld receire their first reinforcements.

$3 \mathrm{rd}$. Belhind these reinforcements at central points in the country would be stationed grand reserves.

Thus, if an attack be imagined at anj point on the const line of a particular section, the firing line of the section rould immediately come into action if on the spot, or move up to the threatened point. Within a fow zninutes the support could by telegraph bo started on its way to replaco the firing line, and the reserro bo on its way to perform this same relief for the support.

To ensure a good working s5stem, the different sections would hare to be serred as far as possible by distinct lines of railway. In this country this conld bo effected without disturbing tho dirisions which the configuration of the coast line dictate.

Thus, in the south-enstern section, the South Lastern Railway and London, Brighton, and South Coast Railway would cover the whole ground, and the London, Chatham, and Dorer Railway (cxcept for Sheerness) would be an alternative route. $\Lambda$ shford and Lewes would be the natural positions for the central points of the firing line, $\mathrm{New}$ Cross the best position for the support.

For the special defence of the Thames, the South Fastern Railkas on the south, and the Iondon, Tilbury, and Southend Railway on the north.

In the eastern section the Great Eastern Railway would practically corer the whole of the ground.

In Lincolnshire, the Great Northern would do the same.,

In tho North-east, the North Fastern Railway, with Pickering, Norton Junction, and Gateshead as central points for the firing line, Leeds as support.

In the North-west, the London and North Western, with Preston as centre, Leeds again as support.

In the Bristol Channel; on both north and south, the Great Western 
Railway could be mado the section line, Bridgend as a fring line ou the north, Swindon as support.

In the South-west, the Great Western Railway again, with Plymouth as firing line centre.

In the South, the London and South Western Railway, with Yeovil as firing line centro. In both this section and the south.western ono Swindon would again bo the position for the support.

Behind all these firing lines and supports would be kept a general reser ro for the wholo. English system, which might bo advantageously stationed at Rugbs.

(b.) Proposed Personnel and Co:operation with Railivay Officials.To ensure the perfect success of any movable defence by sea, the directions for all general movements should cmanate from ono central anthority.

The same would apply to any morable land defence. Generally speaking, it would seem necessary to proride a personnol somewhat on the following lines:- -

(1.) One responsible head, who would be in command of all the const defences of the country, and be in close commanication with tho naval and railway authoritics.

(2.) Artillery Officers in charge of the subsections of tho defence and of the reserres.

(3.) A nucleus battery of artillery in encle section to perfect the s5stem in time of peace.

(4.) Militia and. Voluntecr artillery to work tho sections.

(c.) Types of Proposed . Ordnance. (Hcavy, Medium, Light).-As pointed out.proviously, any gun can be fired from a railway in the direction of the line; relative efficiency would determine the nature of heary gun to use upon railways. For the parposes of this paper, the 22-ton gun has been assumed to be the heaviest ordnance which would bo so emplosed. The use. of these heary guns would seem necessary if the tire of the defence is to reach liko natures of guns mounted in ships.

Too much stress can hardly be laid upon the desirability of using a great number of modern horitzers and mortars to fro out of cuttings, Srom behind hills, \&c.

In medium ordnance the 6-inch B.L. gun and the rarions natures of Q.F. guns would seem to be the best.

For points where landings nro possible, the lighter natures of Q.F.'s, machine, and field gans could be employed.

(d.) Proposed Carriages. - The design of carriages to fire guns from in the direction of tho line is already well established, by their use in European arsenals. Carriages for firing at angles to the line would be a matter for experiment.

(c.) Emplacements for Heavy Guns and Positions for Lighter Natures. -In places whero heavy gans would havo to exerciso an all-round Gre, special emplacements would hare to be prorided. These emplaceinents might take the form of turntables located upon short sidings specially constructed for the purpose. The turntables would be of considerable diameter, their bridges of wrought iron, with hydraulic

roL. IXs. $2 \mathrm{x}$ 
or other suitable bnffers to take up the recoil, the whole swinging in concrete lined pits.

The lighter guns could be fired directly from the main lino from existing sidings, or from specially constructed lines.

(f.) Method of Controlling and Dirceting Fire:-Taking into full consideration the great advances which bare been Inade in the last few years in the art of controlling and directing the fire from guns, even when mounted in concealed positions, there would seem to be no practical difficults in adapting one of the systems to the requirements of the proposed system of railway const defence.

(g.) Estimate of Cost.-Any estimate of the cost of the railway 85stem of coast defence is naturally extremely difficult to reach and yet retain a semblance of probability; undoubtedly a practical survey of the ground would materially alter dispositions mado upon theors.

On the extreme basis that all of the water corered from the existing railways might hare to bo defended, the theoretical disposition of guns of different natures previously exemplified was effected, and their cost, with that of all other requisite matériel for the defence of England, would roughly be-

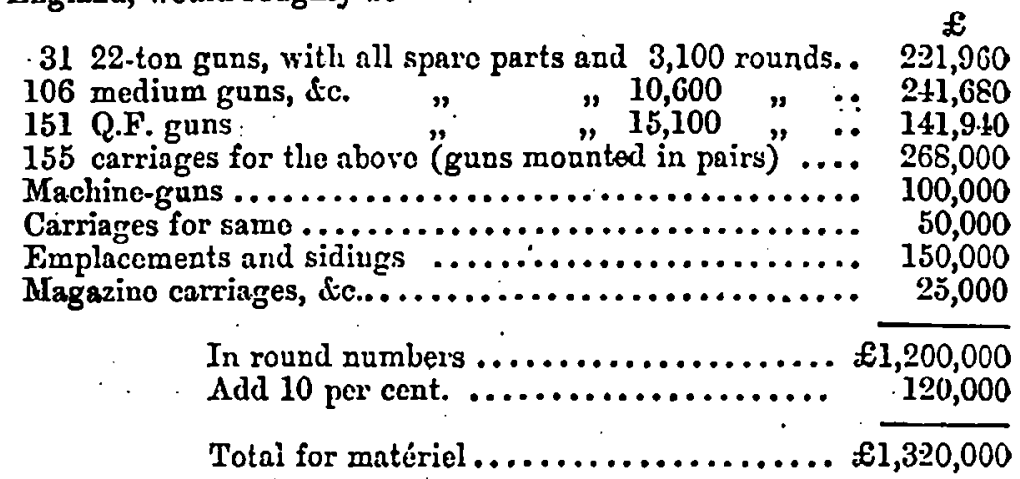

This estimate as stated is not practical, but it affords to the mind a basis for comparison thoroughly with the probable cost of extending any actual system to perform the same rork.

\section{Adrantages of the Proposed System.}

The adrantages of using for the defence of this country a system based upon the ase of gums firing from existing lines of railwny aro numerous and apparent.

lst. 'The amount of resistance which conld be offered at any point of our seaboard in a giren time would be infinitely grenter than by the use of any other practical system.

2nd. The resistance would also be the most economical that could be provided for a general defence of the country.

3rd. Once in working order, the cost of the system rould depand upon the moral and physical life of its gans and their mountings: 
All fixed defences and ships are dependent apon the march of tho science of gunnery, as well as upon the life of the guns they contain, therefore a standard of excellence is nerer reached.

In maintenance expenzes, the proposed system would cost less than fised fortifications, and infinitely less than that of keeping ships in commission.

The cost of personnel would bear the same ratio to other systems as that of maintenance.

thth. The system "could promise the rescue of all unprotected towns from bombardinent.

5 th. At the few landings which exist, a hears force of artillery to oppose any enems could be concentrated in a short space of time.

6th. Tide, storm, and darkness would haro no effect upon the efficieney of a concentration. Fog would delay, not deter.

7th. 'The supply of coal for motive power and of munitions for tho guns would be practically unlimited.

8 th. In accuracy of fire the guns should compare farourably with like ordnance mounted in fixed defences.

9th. In mobility all existing systems would be distanced.

10th. The guns could in most places be concealed by natural features. Naval artillerymen tell as that good practice from ships against forts depends upon one important point, riz., that a distinct object must be fired at. A fort is not deened a distinct object, a particular gun must be selected as a mark.

The result of naral fire against the guns of Alexandria did not, however, tend to show that firing at distinct objects was crer likely to be extremely damaging to that object. If the ships' gans wero obliged to firo at a puff of smoko issuing from behind a hedge, or from out of a catting, it is safe to assume that the effect of the fire would be still less damaging, though it might possibly hare the effect of forcing the milway gan to slift its position from time to time. Smokcless powder would introduco the sole remaining factor requisite for total invisibility.

Finally, the system conld be practically tested in time of peace in conjunction witls our flect mancuvres. Certain sections might be fully mobilized against the attacks of a squadron or cruizers which were to attempt secret aggression of some form along its shores, and umpires decide upon the efficiency of the sjstem. In fact this might be done without actually providing the gans. Railway trucks could represent the armanent, and thas the system bo tried before any great expeuse for gans, \&c., was gone into.

\section{Examples of Ground adaptable to the Inailway System of Defence.}

$\Delta$ few examples in detail of well-known sections in their adaptàbility to the parposes of the railway system will I think cmphasize the enormous comnand which our milmays give us orer the waters which ure immediately contiguous to our shores.'

As examples I hare chosen an estuary, a landing, and au unprotected coast town. 
To follow the phases of possible attacks against these chosen places would be mere theory, and I shall therefore limit myself to describing them in as short a manner as possible, and allow the accompanying maps to speak for themselres as to the chances an enemy would havo in engaging the guns the railways could provide.

\section{Estuary-The Thames.}

As an example of an estuary, I hare chosen the mouth of the Thames. In spare moments I havo been able to make a close study in the field of the railwnys, and the ground from Sheerness to Graresend on the south, and from Southend to Thames Haven on the nortl.

The accompanying map represents the result of this study. The portion coloured blue indicates the water covered up to 4,500 sards, that coloured red the same up to 5,500 .

The dotted line indicates the limits of the 20-foot channel at low tide.

At Sheerness a line of railway runs in from the sonth, and close to tho town dirides into two branches, ono rumning into tho town itself, the other to Qucenborough Pier.

The line into Sheerness would not be of much practical use unless a short extension of it was mado torards the east, in which case a strong reinforcement to the guns of Sheerness might be brought up. The Queenborough line rould afford a position for firing down the Rirer Medway, thereby flanking the dockyard and the forts.

On the opposite bank of the river, at Port Victoria, a good position well concealed behind the sea wall could be taken up. From this portion of the line, guns could fire directly down tho channel of the Dledway towards the Nore light.

Moving in a westerly direction good positions exist for taking an enemy in rererse, sbould he force the defences of Sheerness.

After this point, which is about tro miles from Port Victoria, the line runs behind and up a low range of hills to emerge and sight the Thames close to High Halstow.

At this poiut a good position exists. The railway concealed by small trees and hedges is nt an eleration of 100 feet abovo the Thames, on wliich 5,000 yards away every boat could be plaiuly seen. Behind High Halstow a high-angle firo battery might bo stationed, controlled by a range-finder station in the church tower (210 fect above the river).

Between Halstow and Graresend several very good sites for bat. tcries could be found, the fire of which might assist in the defence of mine-fields in the rirer.

On tho north side the railway (London, Tilburs, and Southend Railway) is mostly situated in low-lying land, and is for many miles within a few hundred yards of the rirer bank.

Excepting for the short stretch from Southend to Shoeburyness, ideal positions for range or position finders are to be found on the hills directly behind the line. 
- From tlic railway itself every funnel and mast in tho channel can be distinctly seen, and direction thus obtained withont difficulty. The guns could not be scen from the decks of ressels, and oven if lonked for from the mast-head would be excedingly hard to distinguish, as hedges exist on both sides of the line.

At Thames Haren a branch line would afford an opportunity for establishing guns to firo directly down the clinnnel.

The piece of country which I have just described bas anfortunately been the only one which time would permit of my studying in detail on the ground. I can only hopo that other important points will after a practical.study lend themselves as readily to the purposes of the railway idea.

The ranges rould not be excessirc, many opportunities for crossfire cxist, no costly extensions of the existing lines would be necessars, and the control of the fire should be thorough and effectire.

\section{Unprotected Coast Toun.}

Iut ns now consider the case of an unprotected coast town. A well-known Admiral of a foreign Power made the statement not loug since, that in the erent of war with this country, he would have no hesitation in bombarding our defenceless coast towns; what would be the probable influence of the railway-gun upon his idea?

If he approached by'day, our lookouts should give the necessary time for bringing ap a henvy force of gans. If, however, he eluded the lookonts and took tho town unawares, his panishment of it could not be of any duration; it would not, for the satisfaction of bombarding a defenceless town, pay him. to risk the loss of a ship nor wasto ammunition, the use of which might at any moment become of rital necessity to him. His best chance of success would, therefore, lic in an approach by night, when be might hope to pass tho lookouts, and open fire on the town (if he happened to have strack it off in the night) immediately after daybreat.

As an example of a place which might be so visited, let us consider the case of Hastings and St. Leonards, which form a single town open to the sea for a lengtli of $2 \frac{1}{2}$ miles.

Double lines of railway approach the town from three directions:-

(a.) From the north-east the South Eastern, entering tho town at tho cast end.

(b.) From the north-west the South Eastern line from Tunbridge, entering the town near the west end in combination with

(c.) The London, Brighton, and Soutlı Coast line from Lewes.

From the map it will bo observed that all these lines run within a short distance of the shore; and that the hills, ife., favour concenlment. Sereral good positions for guns are to bo found on the railways. T'bus at the cast end of the town we find, close bs Hastings station, threc existing sidings well located for fire along the line; on one of these a turntable might without difticulty be laid down for a 22-ton gun; in addition to these three sidings thero is a set of four. more which could be utilized for any natare of fire. 
At Hastings Castle a good obscrving station for a position finder might be established.

From Hastings Station to the Warrior Square Station the line is iu a tannel, which might serre as a shelter if the fire of an enemy becamo too heary. At Warrior Squaro there is an open length of about 200 fards; hero a battery of howitzers and nortars might be stationed, and their fire observed and directed from a church close by. After passing through a second tunnel, Bo-peep Junction is reached; here the South Eastern Railway and tho London, Brighton, and South Coast lines separate, the former running into a deep catting and bearing away towards tho north-west. Excellent positions could bo taken up closo by this junction for flanking the front of tho town or for direct fire out to sea.

The high ground close by would afford sites for range or position finders.

For the abovo notes of the lines about these towns I am indebted to a brother Officer, who has a knowledge of the vicinity and kindly voluntered to give me a few hints.

\section{Landings.}

As I have not actually been on the ground at Dungeness, I shall content myself with drawing your attention to tho accompanjing map of that scetion of the country which scens to demonstrate the possibility of bringing a heary fire of all natures of guns on the water which an enemy's boats would occupy in any attempted larding. I have lately had the opportuaity of visiting another of tho -dangerous landings of the country, that of Clacton. Here, close beside the row of ancient martellos built for the parpose of denying the landing, a line of railway could bo built at a rery small cost. The gans mounted npon it rould bo hidden behind tho sea wall and conld cover the water which an encmy would occups, both in lnnding and in corcring his landing.

In conclusion, I may be allowed to recapitulate the leading points of my argument.

'The strong point of our defensivo position in England is, as I submit, our enurmous milway power. Whether we regard it from the point of railway mileage open, as compared with square mileage of area to be defended in Great Britain and Ireland generally, or whether we look to the length of our extended const line as compared with the railway mileage nt or nen that coast. line, and thercforo locally available for its defence, the conclusion is ono and the same, namely, that our defensive railway power is far greater than that of any other country.

What the nature of our defensire position should be is not within the province of this paper, and I trast that I have not made state. ments which are construable into opinions on this rexed subject. What I have wished to point out is that the railway system of coast defence is equally applicable to all shades of opinion. 
The weak point of England's defensive position is, as I have submitted to your judgment, our existing deficiency in gun power. Onr const defence is admitted to bo very partial and incomplete. It leaves great lengths of our seaboard and important commercial centres on the coast, nearly if not quite undefeuded. And when we look inland, we find a similar deficiency of gun power for that field force which successive generations of responsiblo Mrinisters havo thought to be a necessary provision for our defenco in the event of invasion.

Ify argument thereforo is, and has been throughout this paper, Why not use our strength to correct our weakness? Why should wo not

Tabie.-Details of English Coast Iine by Counties.

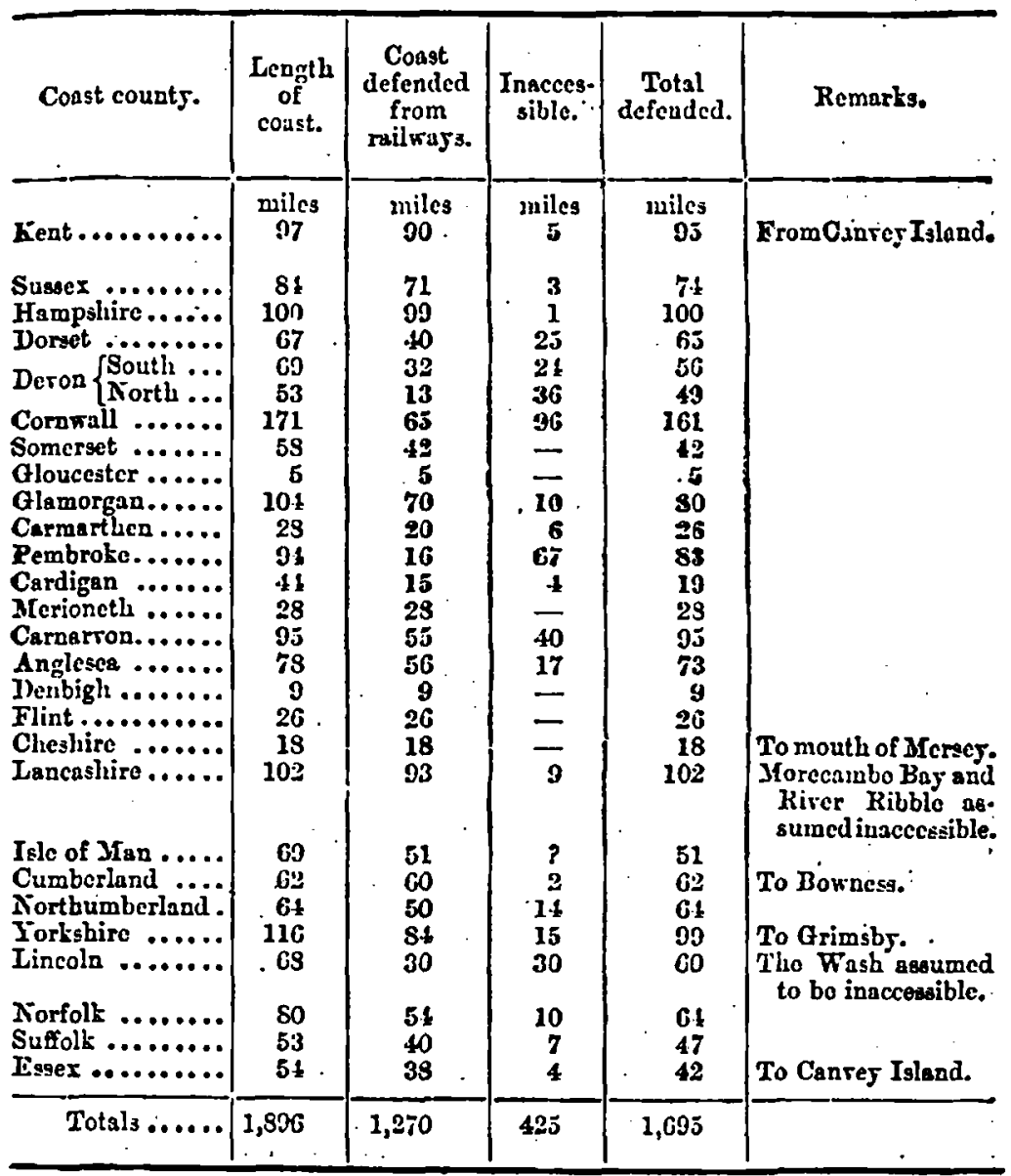


turn to account the cuormous adrantage which our great railway power gives us to concentiate erery arailable gun at a threatened point in tho right and the shortest time, which the proper utilization of our railways can and will do; thereby, as I submit, practically doubling or quadrapling our available gan power?

The Crarnsas: Wo hare been listening to a rery instructire lecture upon a subject which must bo new to meny of ug, and I am sure there are many who will be able to help us by offering sone remarks in the discussion which is inrited.

Colonel F. R. WETHERsD: I rise not with'a rick of criticizing any part of the lect ure, and I must congratulate the lectures on the intelligence ho has exerciscd, and the large amount of labour and time he must hare expended in worbing out in detail theoretically bis plan of operations. To take it ehortly and briclly, it is suflicient to look at the nap, and let $\mathrm{u}_{3}$ admit for example that it is possible to fire guus of heary calibre from our rail way metals os proposed, subject, of course, to certain modifications which could doubtless be casily curried out. If you look at the: coast line of Fngland and consiler our present sjstem of defence, the distauces our ships would hare to trarel round that coast, you will sec what a number of ressels we should require to be constantly on the more and how our existing Flect, which would bo requircd in all its strength to strike a blow, and protect our commerce, would be supplied. Tow, looking at the map, suppose we had a large rescre of hesry guns mounted and equipped at Rugby, or some more suitablo ccntral position, how easy it would be to more dircet to uny giren point of the outcr circle, which our railiray ejstem prorided for. Fou could more jour guns in one quarter, or eren onc-tenth, of the time that it would take to get a ship round from point to point of our extended eeaboard. I hare lietened to the lecture with considerable interest, I may say, almost with a kind of parental fecling, not because as an old man I rise to compliment the joung lecturer, but ho has taken up wy child, and naturally the parent alwass likes the man that fondles his offepring. I am getting on in ycars myeelf, and I am therefore glad to sec that a rers joung man bas risen up and taben an interest in this subject. Twenty rears ago I suggested the rery eame thing. I wrote to the War Office proposing. it. . I will read you a portion of $\mathrm{my}_{\mathrm{y}}$ letter. $M_{y}$ infant met with the usual War Office atteniion, and I suppose it nos put aslecp in the pigeon-hole, and if this young man had not raised the question it might hare lain there long ufter I had been laid in the grare. "January 4,1871 . Sir, as the defences of our country are now oceupsing uuch national concern, I hope I may not be considered presumptuous in briefly and rery cuperficially offering a suggestion relative to this important subject. In riew that all our heary ordnance is at present mounted in fired pozitions and incapable of concentration at anj threatened point of our coast, or eren at any particular face of a fortification without considerable labour, I nould proposc to utilize gencrally our railway system for defensire purposes, and would mount all our guns on whecl carriages, so that they could be mored along anj of our lines from point to point: the adrantages of such a syetem must bo obrious, so not ouly would it cnable us to concentrate our artillers with orerwhelming force at any giren point, but guns on such morable carriages could be fought with infinitely less exposure to the men." This was the reply I receirca from the Wur Ofice:- "War Oflec, 13th Janunrs, 1871. Sir, I am directed by tha Sccretary of State for War to acknowledge the receipt of jour comnunication, dated 4th instant, containing suggestions for the adaptation of the railway eystem for defensire purposes by mounting guns on carriages which could run on the lines: and for the defence of the metropolis on a similar flan." I am not awaro that any gun was crer preriously mountel for firing purposes upon a railwas whed-carriage plat form before this, but not being either a gunner or a snpper, or in any way mixed up with gunnery cxperiments, I am unable to epcuk from personal bnowledge. Shortly after this, at the proof butts at Woolwich, an 81-ton gun was thus mounted and fired on the rery principle I proposed. In 1877 I wrote to the "Times" as follows : it was printed in the "Times" of the 25th May, 187\%, Leaded- 


\title{
"PORTABLE-BATTERIES.
}

\author{
"To the Editor: ot-khe 'Tines.'
}

"SIR,-Any suggestion which has for its object the rendering of our ecagirt islnnd so inpregnable in itsclf against the postibility of inrssion or injury from Lostile forces that our powerful Nurs may be left free and unfettered by homo fears or necessities to protect our extended Colonies and commerce, or to strike a blowwith all its power at anj giren point, cannot fail to be of interest at the present time, and will, I trust, plead a suficicnt excuse for soliciting spuce in Jour columns to draw attention to my proposal.

"Our present conscious sccurity is based mainls on the command we possess on the high sese, and should any combination of circumstances render our flects powerless to cope with the encmies' naries, the inrasion of this country would admittedly be feasible. In such adrerse circunstances we should depend for the defence of our coast on the existing fortifications, supplemented by such carthworks as time permitted, together with the aid of all the gunboats and torpedo craft we could conmand; our telegraph system would cablc us to dircet ous flonting batterics and all arailable troops to procecd by most expeditious means to the points threatened. The objections that occur to me in trusting exclusirely; to this means of defenco are-

" 1 . All our scattered or detached forts, with their fircd complement of guns, men, and material, wealien our yowers of concentration, for these forts cinnot be denuded of troops, as not only must the mnterial and stores be protected, but the. tranefer of gunners to any other point rould be of rers little ecrice mithout their guns. Again, an cnemy once effecting a landing and getting possession of one or more of these fortifications rould sccure a eolid armed basis of communication, which, supported by their nary, would render their position impregnable.

“2. Our gunboats and tornedo craft, besides being largely denendent on the reather, and haring rery long distances to trarel round tho outer circle of the consts, would not be cnabled to concentrate at any giren point in sufficient time; in fact, the cnenis, lanring command of the Channel for the time being, could bar the approach of any ressels of this bind on both flants of their discmbarting troops.

"The collecting of a large force of Jilitia and Toluntecrs at any particular spot rould occupy considerable time.

"Again, the enemy would, in all probability, make a feint to attack on two or more points, and baring thus drawn our forces in tliose dircetions would, under corer of night, run with the main body of his troops for unother part of our shores.

"Our island Lome, being proridentially surrounded by water, possesses the strongest natural barrier against inrasion that can possibly crist, and it appears to me that if we proride the means of concentrating with unerring certainty a crush. ing force of artillers, with guns of hearier calibre than cren the war-ships of the invader could command, on any giren points of the const, before the enemy could possibly eet foot on the shore, it would be jmpossible for the ressels of au invaling force to approach near enough either to discubark or cover the landing of their men.

"II propozal is simply to take the full ndrantage which our railway systcm, in connection with our insular position, affords, and provido powerful morable butteriee, which can be ecnt fully equipped in figlting order direct by railway to any required point, and the recent experimental trials of the 81 -ton gun have prorcel that the heaviest ordnance can be mored and fought on railway metals with considerable adrantage, the incline of the rail at the firing point forming aluost an automatic platform, the recoil taking the gun up the incline, where it is licld in position by the braise, and when liberated returns to the firing point by its owv momentum.

"In connection with our present inain lines of railwas, which probably would require strengthening at certain points, I would construct branch lines or sidings leading to crers strategical point of our coast and into crery fort, as far as possible; 
with requisite platforms, cither on the incline principle, turntable, or other mechani. cal arrangement. Theso branch lines during peace would, doubtless, be of somo small commercial ralue. I would mount as unany of our hesriest guns as practicable on railway gun-carriages, so that they could be mored by rail from one face of a fort to anotlicr, and from one place to another. The locomotircs required for this serrice could be so mechanically constructed as to facilitate the losding of tho guns by stcaur power, and thus sare manual work. I would suggest three large central depotts, where a number of guns this mounted, fully equipped, and ready for use, should be lept. Those ccutral depots might bo so corstructed as to form an inner circle of fortifications to defend the metropoliz. At cach of these stations the regular Militis and Toluntece Artillers might be instructed in crerything that pertains to the rrorking of these guns-the construction, repair, and destruction of railway lines, besides the formation of a locomotive corps specially trained to conduct. tho traffic.

" Besides the drill and instruction imparted at theso stations, a number of these heary guns, fulls equipped, with proper complement of men, ammunition, and material, might be occasionally moved to different points of the cosst for drill and gun practice. Practical instruction of this kind rould. bo highly calculated to interest our Voluntecr soldiers, who ehould be giren ercry cncouragement and opportunity to reuder thenselres eflicieut artilleriats. The cost of such a system would not be great, for when once we liare cstnblizhed a meuns whereby our heary guns, as well as men, can be mored expeditiously from place to place, we can afford to diminish the number of our seattered forees and present immorable batteries.

"I haro merely stated ny ricks superfoially; the details are easily worked out. "I remain, Sir, Jours fuitlifully,

"Woolwich, J1ay 24th, 1877."

"E. K. WRTHERED.

Immediatels after this letter appeared, I bad a number of copics printed for circulation, to which I appeaded the following footnote :-

"If, in addition to connecting some of our light-ships by telegraph cable with the shore, some prorision were macle for running out, in the crent of war, from these ships a further length of cable, some 10 or 20 miles out to sea, and there establish. ing a temporary telegraph post, our cruizers would, by theso means, bo enabled to communicate auy morements of the enemy or other information, without loss of time or haring to quit their cruizing ground."

I am sn old-fashioned man mysclf. I prefer one practical test to erer so many theoretical ideas, and firing at a direct anglo on a railwsy is a point that requires rery careful practical experiment, because we are taling the lino at the rerg rcakest point. Tho rails, the sleepers, bolts, and erersthing are tsten at tho westeot point. 'The wheels, metals, chairs, slecpers are constructed msinly to bear the rerticsl strain, and the sudden slsock of digcharge would throw a rery considersble pressurs on tho outer rnil. The elcepers also run across, and the bolts which hold tho lecpers run with the grain in the direction of tho side pressure. These are all rery weak points. Therefore it would be inpossible, I think, for any mathematical calculation to arrive at any conclusion as to whether the carriage and the railway metals would bear right-angle fire. Then if the gun was fired from any part of $s$ curre, if the recoil is towards the upper side, the raised outer rail would strengthen the power of resistance, but, if the recoil wns in the rererse direction, tine carriage would stand partly tilted up in the direction the recoil would force it. Tl:ese are matters of detail. Only admit the principle, and crersthing else can be worked out without much difficulty.

Colonel Kexsisotos, R.A. : I have been referred to in tho lecture concerning the calculation of the orcrturning effect of fire at right angles to the line of rails. This problem is not cass, bccause it is difficult to culculato the cnergs of recoil exactly. It is not sufficient to take it as due only to the momentum of the projectile, bccausc there are other causes which mast not be neglected, as bas been ably shown by Dr. Anderson, F.R.S., Director-General of Ordnence Factories. There is the force expended on driving the air out from the bore of the gun, which alone 
is too much to be neglected. There is also the great amount of the reaction due to the crpansion of the powder gas on learing the bore, besilles the actual relocity acquired by the rery considerable weight of powder. By Dr. Anderson's calculations it would appear that the energs of the recoil of tho G.inch B.I. gun ia probably about half again as much as the energs of recoil which would be due to the momentum of the projectilo alone. This rould bring the anount to 25 foot-tons at most, taking the muzzle relocity at a rather larger figure than the lecturer has giren, nemely, close upon 2,000 feet per secund, which $I$ beliere is nearly correct. Irsting then theso assumptions concerning the cnergy of recoil, and taking into consideration the arerage amounts for the weights of the truck and mounting that might be emplored and the position of the centro of grarity, as well as the width of the track, I find that, eren if the whole of the energy of recoil were available for upsetting the truck, there would bo sufficient stability to prerent a complete upset. In fact, howerer, a large amount of cuergy of recoil wonld be aboorbed by the hydraulic buffers, aloo by the action of the springs of the truck; so that I think that it mas be fairly be assumed on mathematienl calculations alone that the 6 -inch gun might be fired st right angles to the truck. Further, I hare considered the ques. tion in connection with experiments with the 40-pr. R.B.X. which hare been alluded to, the cnergy of recoil in that inatance not bcing unore than 4 or 5 foot-tons, or about one-fifth of the smount for the 6-inch $\mathbf{B}$.L. It appears that the guncarriage might hare in that casc becn able to recoil about 6 inches at most, whereas for the Tarasseur carrisge used for the 6-inch B.I. there is a recoil of 3 feet allowed. This rould compensate for the grestcr encrgy of the 6 -iveh 13.I. The ncw Tavascur carriage for garrison serrice is only constructed for a recoil of 1 feet, which according to my calculations would, I think, be insufficient, because the question is not merely to consider what will prerent the carringe from orerturning, but rather that the front trucks should not leare the rails at all. I am satiefied that with a recoil allowed of 3 fect the truck would remain safely on the rails. I should like to say a fer words on some further points connected with the lecture. I thisk that the system which has been brosght before us is adinirably adapted for the bigh-angle fire, which has been prored 80 effectual, and that tho apparently long ranges the lecturer has taken, up to 7,000 Jards, are not by any nenn ercessire then considered in connection witls ranges at which high-angle fire las been experimentally employed witl rery great success. Experiments hare been made at the Isle of Wight, extending up to 10,000 jards, when a moring raft, the size of the deck of a ressel, has been successfully hit. Further, I hare just been informed that at Shocburgncss the practico has becn adopted of firing guns from curred mils, thus casily obtaining any required direction. It has recently been suggested that all our lighthouscs ought to bo conuected by telegraphic communication with the land, chicfly for the purpose of giring information concerning shipwrccis that may occur near them.- This would be invaluable in conncction ritb the question of coast defence, so that the carliest information might bo obtained. I think the lecture is very instructire, as showing the short period of time within which a rmawents of rery considerable power can bo brought together, and must altogether be considered a valuable contribution to the resed question as to which of the sister Services, Army or Nary, should be responsiblo for const defence.

Captain Bexpers, R.A.: I should like to say a fer rords from the point of rien of the man at the gun. Colonel Kensington says 7,000 jards are not extreme for high-angle firc, but I think with the medium guns, the 6 -inch guns to which the lecturer ulludes, that we should find considerable difficulty in hitting a ship at 7,000 yarde by direct fire; in the first place, cren if that rango was taken from the gun itself. In many cases, 35 you see by the nap, the town to bo bombarded would be come little distance ncarcr to the ship than the gun would be. The ship also would be firing at a rers large object; there nould be no necesoity for her to anchor as long as she throws her shells anjwhere into the town. We sliould hare, therefore, the difficult 5 of firing at a moring object. I aru diffident about easing anything about position-finding in the prescnce of Major Walkin, who, I hare no doubt, will be able to orercome any difficultics that will bo raiscd, but, at present, it would be vers difficult for us to use high-angle fre directed by position-finders, wbich are a necessity to accurate high-angle firing, with guns firing from trucks and moring on 
railway lines. Te are dependent for accuracy on direction, and without accurately laid training arcs $I$ do not sec how you are to get good regults. Then, agnin, there is the electric communication of ragges and training, and I do not. sce how that is to be managed with guns running freely on railway lines. I think that points to the necessity of haring sluort sidings runving ints emplacements for guns and howitzers. Inlso think the supply of amzaunition in open trucks without magazines would be rather a hazardous experiment. I do not think it would tend to confidence in exring the guns. It would be difficult also to supply ammunition to indiridual guns if you had firc or six guns in a row, unless jou bad a siding or branch line which would cairy the arnmunition round. I think the question of interruption of traffic has hardly been giren sufficient attention. I fancy the War Office arrange: ments for moring troops and stores would be rery much interrupted if a considerablo portion of the line was to bo taken up for tlic use of the guns. I fancy it would lead to friction, to say the least of it. Then, again, the orduance would require to be practised from in peaco-time, and there is local trafle to be considered. I do not know whether the railway companies would be ready to give up a portion of their lines and interrupt trafic without considerable compensation. There is one point the lecturer has not alluded to, in which. I think the system would be of rery great ralue. We depend, in time of uar, rers much for our const defence upon the serrices of the Auriliary Artillery, Militia and Voluntecrs. At present the great majority of them hare littlo or no training with modern B.L. weapons. As to tho Militia, I may sas, without exaggeration, most of them hare to train with the old 61-prs., though they are eent occasionally at long interrals to be trained at the forts. Under some system such as that proposed, instead of the whole regiment going to the gune, we can hare the guns sent up for the use of the Militia and Foluntcer regiments at their own headquarters. That, I think, would do awas with great part of the dificultic we Lare at present in training our Ausiliary Artillery in the use of new tspe guns.

Licutenant-General Lacriv: It is, I think, rather en interesting fact that the first Canadian Mlilitars College Cadet who lus delirered an address in this theatre Elould haro spoken on the subject of the protection of the shores of lingland. It docs strike me as rather a peculiar thing that his nttention should first hare been directed to the defence of the mother country. As regards this subject, it strilses me that perlaps he is suggesting too much, and so may orerdo his proposnl. He telis us in tlie same adelress that we are short of guns. IJe then proposes to lock up a rery large number of our guns by mounting them on these carriages. It seems to me, spealing not of course as a gunner, that it would be more desiruble to fit the carriages so that the guns could be readily placed upon them whenerer required, so that they could be utilized for that purposc, ratlicr than to lock up perminentls a large portion of our armament, which may or may not require to be used elsewhere. Besides, it scems to me you sliould not make jour guns firtures on the railway trucks, but hare them detaclable and arailable to more into commanding positione where the railway track does not and cannot run; hevec it rould surcly be better that the trucks should be fitted to receire the guns, so that they could be utilized for this purpose, but should not be permanently connected. Again, I think, when he suggests putting thesc heary guns on the railway carriages he is again going rather far. For light guns to meet miders it seems to me to be a rery ecrrictable and feasible plan; but to deal with heary guns and to expect that they are to take tho place of forts against ships does eccm to we tu be going a little beyond what we aro at all prepared for at present, and way destros the chance of carrying out a rers reasonable, a rery fair, and admirahlo suggestion. I throw out these idcas, spesking more as an infantryman, a man accustomed to other work, than as a guuner; bus we are much indebted to the lecturer for the care and thought he has bestowed on this norel and important subject.

The Cmarryas: Perhaps Jajor Watkin can giro us some information on this subject?

Jrajor WATkIx: I lave not studied the question enough to answer any of the questions raised, because I understood the lecturer only to put the matter forward as a scheme, and not in detail. I think, when we come to matters of detail, wo could possibly mect the objections raised. If jou could wount the guns on the 
carriage, I think then you come to the question of laging the guns, but I should be very sorry to lay it down esactly how it is to be done.

ilie Charrsax: I think that the lecturer has done good acrice in bringing this question forward and suggesting that a morablo armament, such as is recognized as part of the defence of a position occupied bs a chain of forts, might bo utilized for the defcuce of the country at large, for, if not applicable to the extent ho euggest 3 it might still be ndopted for special sites. Ilis proposals are not altogether ner. We hare been told by Colonel Wethered that somerliat similar proposals were submitted by him to the War Ofice in 1871, and the Index of Lectures that hare been delirered in this Institution shows that the subject was also brought forward by an Officer of the 70th IIighlanders in 1865, so that we may suppose that what his occurred to sereml minds has doubtless a good deal in it. Tho lectures's propozals would euable one gun to dn the work of two or more, for, by laring the guus concentrated and mored to different places on the coast where they might be wanted, they could do a great deal better eerrice than if thes were kept locked up in ono or two places. Besides which, nt a time of inrasion or attack in this country, phen crers arailable horse would probably be taken up, wo should liare the adrantwge of rapidly getting the guns by rail somerhere near the ploces where they would be wnnted, instcad of haring to rely cxclusirely upon horse power for the purpose. Wic hare had an cstimate put before us of $1,320,000 l$. for cloing this; it is a pretty large sum, but I fancy it is not quite enough. It does not include a grest many accessories that would be requircd, such as the cost of proriding storehouses and of purchasing land and making sidings and gun emplacements, which would be necesenry, not onls to prerent the main lines being blocked by the armoured trains at a tinic when troops would hare to be hurried up to points whero the attack was likely to take place, but also for the efficient working of the guns. Considering tho long range which is proposed for the guns to fre orer, I understand thint high-uagle fire is intencled, the guns to be worled by mens of the position range-finder from places where they rould not themselres be seen. I doubt whether Mrilitia or Folunteer Artillers would bo able to do much accurate practice at bonts moring sbout under such conditions. There are, howerer, others inuch better fitted to gire an opinion upon this point than I am. Machine and other guns for direct firing to oppose a landing could not well be used from the lines of railways; they would isare to be brought nearer the points to be defended. The London, Brighton, and South Coast and other lines referred to by the lecturer are pretty close to the seit, but I think there are few places on those railwajs where we could netually put guns on the metnls and look over the sights of those guns to fire at any places where troops might probably be landed; nrmngements rould thereforo hare to be made for getting such guns to the front, to points where thes could be used. The Officers of the Engineer and Railway Volunteer Staff Corps might haro a good deal to sar in the matter dealt with in this lecture. They would probably hare to make tho traffic arrangements in great measure for the armoured trains, if any such scheme as is proposed here were to be adopted, and I am sorrs nono of them happen to be hero to-day to help us in the discussion.

Lieutenont Gruodro, in reply: MI first thought of this idea was more in connection with eiege attack than coast defence, and in its bearing on siego attack I can see no reason why the idci is not quite appreciable. I hare esamined the country round Paris and Belfort, and apparently tho henviest guns, if neccssary; could bo brought up and laid dircetls on the forts, quito out of rango of the guns that are mounted in then. But as the question of const defence was one wilich more directly affected our own country, I abandoned the question of siege attack and went into coast defence. I then became aware, by going through back papers, that Colonel Wethered and Mr. Walker, of the 79th filighlonders, had proposed the schene manj years ago. At that time, unfortunately, a great manj of our prescnt railwajs were not constructed, and the scheme was not so feasible as it is to-day. Captain Bunbury has spoken of a few objections to tho scheme. The Iecture to-daj was nerer intended to go into detail. It eccms to mo that if the general idea is sound there certainly could bo no difficulty in the details which might not be got orer in some reasonable way. He has ruised a fow objec. tions; one is the supply of ammunition. I can sec no diffeulty in this matter. 
Special cars are prorided, which would come up with the trains and be left at a short distance from the place where the guns would tako up their firing positions, and aleo ns to the supply of the ammunition from those cars to the guns. The lines are double, and the simplest method would be to ure the second line to run a small car on, and thus take up tho ammunition to the guns. In the matter of interruption of traflic, Captuin Bunbury, by admitting the fact that an cnems mas bonbarding a town, certainly admits tho fact that the traftic would be interrupted, and in such a case I do not think any regular railway trains could run upon them. Practice in pence-time, which Captain Bunbury spoke about, is, I think, one of the things which makes the acbeme peculiarly raluable. It could bo practised in peacetime and thoroughly perfected. General Lauric spoke about the locking up of the guns. I cannot quite sec myself how one could diumount the guns. They need not necesarily bo guns of the latest pattern. We liare any number of guns in the country which are not used because guns of later pattern aro superseding them. If wo aeparate the guns from the carriages, the scheme could hardly be ready in time of war. The scheme would hare to be studied rers carefully in peace-time, and all the detrils worked out. General Laurie also spote about replacing fortifications by the use of these henry guns. That, I think, was the last idea I lind in my mind in this paper. What I did mesn was that we could not hope to ertend the present fortifications, and that there were many points on the const which were totally undefended, and here the scheme could be used to greater adrantage. - If we only bring up light guns we maj hare hears ship's guns to deal with, and I cannot therefore sec that the exclusire use of light guns would be adrisable; therefore, I proposed at the moro important points to put one or two turntables, in order that these heary guns miglit serro three or four places. If jout put a coast battery for each place it would reach the cost of fifteen or twenty of these guns, or probubly the cost of the heary guns for the whole of the country. General Dawson-Scott epole about blocking the concentration of troops coming up in case of inracion. Undoubtedly there would be some objection to this, but, at the sume time, it is laid down that it docs not pas to catrain troops unless thes hare 20 miles to go. I think it is 30 or 35 miles in Europe, but in this country, on account of our numcrous railwass, Ke assumo it to bo 20 miles. At any of these points it rill bo noticed that the guns would be up long before the troops would begin to entrain. Asbford is only 17 miles from Lydd, and tho guns would bo in position before tho line would be used, and therefore would not cauec a block. This would also seem to be the case at Clncton, 33 the guns would only have to trarel from Ipswich. These are the two most dangerous landings in the country. At other points; if the bombardment of 2 tonn is going on, I cunnot ece how the ordinars traffic could possibly go on. Therefore, I hould think no interruption rould take place. In conclusion, I must thank the Offieers who have bindly helped me. This paper is not an un. dirided effort, a great many pcople haring rery kindly assisted me in ercry way.

The Cusirysx: It only remains for me to ask jou to join me in thanking the lecturer for this vers intercsting paper, and also to thank those gentlemen who hare taken part in this discugsion. 